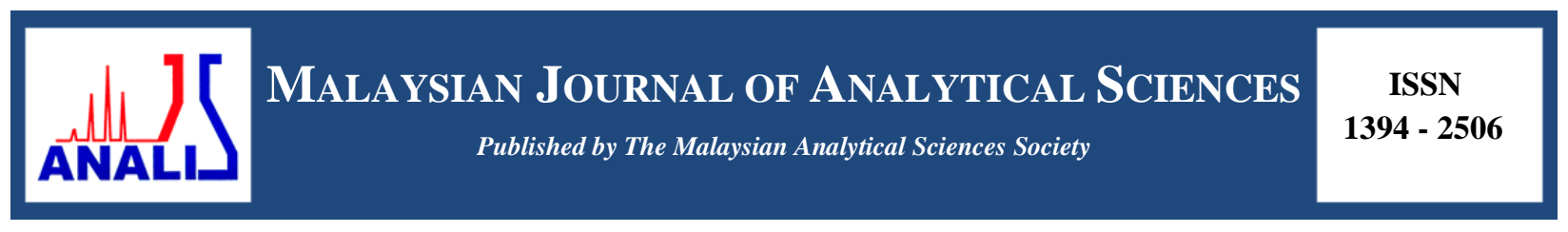

\title{
Candida rugosa LIPASE IMMOBILIZED ON DIETHYLAMINOETHYL- CELLULOSE (DEAE) FOR ESTERIFICATION OF BUTYL OLEATE
}

\section{(Lipase daripada Candida rugosa Tersekatgerak pada Dietilaminoetil-Selulosa (DEAE) untuk Penghasilan Ester Butil Oleat)}

\author{
Mohd Basyaruddin Abdul Rahman ${ }^{1,2}$, Ruhil Naznin Azaman ${ }^{2}$, Emmy Maryati Omar $^{1,2}$, \\ Muhammad Alif Mohammad Latif ${ }^{1,2}$, Emilia Abdulmalek ${ }^{1,2}$ \\ ${ }^{1}$ Integrated Chemical BioPhysics Research, Faculty of Science \\ ${ }^{2}$ Department of Chemistry, Faculty of Science \\ Universiti Putra Malaysia, 43400 UPM Serdang, Selangor, Malaysia \\ *Corresponding author: basya@upm.edu.my
}

Received: 19 August 2018; Accepted: 14 May 2019

\begin{abstract}
Lipase from Candida rugosa was immobilized onto diethylaminoethyl-cellulose (DEAE) through physical adsorption method with high percentage of protein absorption obtained at $84 \%$. The lipase-DEAE was used to catalyze the enzymatic esterification of butyl oleate by reacting oleic acid and butanol in hexane. Butyl oleate, an alkylic ester of long-chain fatty acid is now in high demand to produce biodiesel. The effect of reaction temperature, thermostability of the immobilization lipase, stability in organic solvent, leaching with hexane and storage studies under various conditions of immobilized lipase were investigated. The optimum esterification was found to be up to $90 \%$ yield. Only a slight of lipase leached out after being washed by $20 \mathrm{~mL}$ of hexane. This showed that lipases were strongly attached to the DEAE support via physical adsorption method, and it could be used as industrial biocatalyst.
\end{abstract}

Keywords: immobilized enzyme, lipase, cellulose, esterification, biodiesel

\section{Abstrak}

Lipase dari Candida rugosa tersekatgerak pada dietilaminoetil-selulosa (DEAE) melalui kaedah penjerapan fizikal menunjukkan peratusan penyerapan protein tertinggi pada kadar $83.4 \%$. Lipase-DEAE digunakan sebagai mangkin untuk sintesis berenzim butil oleat melalui tindak balas asid oleik dan butanol di dalam heksana. Butil oleat, satu ester alkilik dari asid lemak rantai panjang kini mempunyai permintaan tinggi untuk penghasilan biodiesel. Kesan suhu tindak balas, kestabilan terma lipase tersekatgerak, kestabilan pelarut organik, pelunturan dengan heksana dan kajian penyimpanan pada pelbagai kondisi lipase tersekatgerak telah diselidiki. Hasil tindak balas pada keadaan optima didapati menghampiri $90 \%$. Hanya sedikit kuantiti lipase yang hilang selepas proses pelunturan setelah dicuci oleh pelarut heksana $20 \mathrm{~mL}$. Ini menunjukkan bahawa lipase telah tersekatgerak dengan kuat pada bahan DEAE melalui kaedah penjerapan fizikal, dan ianya boleh digunakan sebagai biomangkin industri.

Kata kunci: enzim tersekatgerak, lipase, selulosa, esterifikasi, biodiesel

\section{Introduction}

Immobilization of enzymes and proteins onto insoluble materials forms the basis of many biotechnological processes and analytical devices. The main reason of immobilization is to ease enzyme-product separation and to allow enzyme recyclability, persistency of functional activity rather than to stabilize enzymes and proteins. 
Previously many materials have been used to immobilize enzymes such as layered double hydroxides, [1] mica [2] and metal organic frameworks (MOFs) [3]. Several properties are desirable for the continuous operation of the apparatus setup for the bioconversion using an immobilized enzyme reactor. Immobilization is bound to lead the changes in the environment of the enzyme, and hence cause changes in the observed properties [4]. The most commonly used support for enzyme immobilization is the ion-exchange resins as these readily adsorb most protein.

Diethylaminoethyl-cellulose or DEAE-cellulose is the most widely used of all the cellulosic ion exchangers and most variable in quality. In addition to provide a low density of charge and easy penetration by large molecule, this cellulose adsorbent offers a supporting matrix that is hydrophilic and consequently minimizes the hydrophobic interactions that complicate the adsorption of protein to ion exchange resins. Because of the ready penetration of substantial portion of the cellulose structure by protein molecules, the capacity of adsorbents such as DEAEcellulose for the adsorption of protein is not strongly affected by particle size [5]. One of the earliest studies found out that immobilized amyloglucosidase on DEAE-cellulose showed greater stability at $50{ }^{\circ} \mathrm{C}$ than the free amyloglucosidase [6]. DEAE-cellulose was also reported shifting the $\mathrm{pH}$ optimum of amyloglucosidase to a lower value. In another work, immobilization of a bacterial nitrile-hydratase on DEAE-cellulose had slightly decreased the activity's optimum $\mathrm{pH}$ and increased the optimum temperature and thermal stability of the system [7].

Major advantages of adsorption as a general method of insolubilizing enzymes are that usually no reagents and only a minimum of activation steps is required. This method offers cheaper alternative as it can be carried out easily and less disruptive to the enzyme compared to other methods that focus on chemical interaction such as covalent bonding and cross linking. Candida rugosa lipase is a well-known microbial lipase, which hydrolyses all ester bonds of natural or synthetic triacylglycerols. Lipase from Candida rugosa has also been widely used for several stereoselective esterification and transesterification reactions in organic medium [8]. Esterification of oleyl alcohol and bioalcohol (e.g. ethanol and butanol) give a fatty acid ester (e.g. ethyl oleate and butyl oleate) that is useful for pharmaceuticals and cosmeceuticals. It can also be used for biodiesel production as the main components of biodiesel are alkylic esters of long-chain fatty acids. Other than the alkali-catalyzed transesterification of a vegetable oil with alcohol, enzymatic reactions could also be used to produce these esters in the biodiesel industry.

The use of lipases to catalyze the esterification step is attractive, because they can be used under mild reaction conditions. However, several challenges must be overcome in order for the enzymatic route to be economical as current commercial immobilized enzymes are expensive which costs approximately 1,000USD per/kg [9]. This has stimulated a search for cheaper immobilized lipases that have high activity and stability. Therefore, the aims of the current work were to study the immobilization of Candida rugosa lipase onto DEAE-cellulose and to optimize the synthesis of butyl oleate, a model system for biodiesel synthesis by enzymatic esterification.

\section{Materials}

\section{Materials and Methods}

Lipase from Candida rugosa (E.C.3.1.1.3, Type VII) and DEAE-cellulose were purchased from Sigma Chemical Co. (St. Louis, MO). All other chemicals (butanol, oleic acid, sodium hydroxide) and solvents (hexane, ethanol, acetone) used in this study were of analytical grade.

\section{Water extraction of lipase}

Commercial lipase from Candida rugosa was partially purified by dissolving lipase $(1.5 \mathrm{~g})$ in distilled water (15 $\mathrm{mL}$ ) with continuous stirred for 30 minutes in the lowest stirring manner. This mixture was then centrifuge at $10,000 \mathrm{rpm}$ for 15 minutes. The supernatant was used as partially purified lipase or stored at $4{ }^{\circ} \mathrm{C}$ prior to use.

\section{Immobilization of lipase}

The partially purified lipase $(15.0 \mathrm{~mL})$ was added to DEAE-cellulose $(2.0 \mathrm{~g})$. The mixture was shaken at $100 \mathrm{rpm}$ in a water bath at room temperature for 1 hour. The immobilized lipase was separated by filtration through Whatman no. 1 filter paper (pore size $11 \mu \mathrm{m}$ ). The volume of supernatant after filtration was recorded and kept for protein assay. The immobilized enzyme was lyophilized at $-40{ }^{\circ} \mathrm{C}$ in a freeze drier. 


\section{Protein assay}

The amount of protein content before and after immobilization was determined by using the method of Bradford Coomassie brilliant blue assay procedure using bovine serum albumin as standard [10].

\section{Esterification assay}

Enzymatic esterification tested consisting of native lipase $(0.3 \mathrm{~g})$ or DEAE-cellulose-immobilized lipase $(0.3 \mathrm{~g})$, butanol $(4.00 \mathrm{mmol})$, oleic acid $(2.00 \mathrm{mmol})$ in hexane $(2.0 \mathrm{~mL})$. The mixture was incubated at $30{ }^{\circ} \mathrm{C}$ for 5 hours with continuous shaking at $150 \mathrm{rpm}$ in a horizontal water-bath shaker. The reaction was terminated by dilution with $3.50 \mathrm{~mL}$ ethanol:acetone $(1: 1 \mathrm{v} / \mathrm{v})$ and the remaining free fatty acid in the reaction mixture was determined by titration with $0.15 \mathrm{M} \mathrm{NaOH}$ using an automatic titrator ABU91 to an end point of $\mathrm{pH}$ of 10 . The activity was expressed as $\mu \mathrm{mol} / \mathrm{min} / \mathrm{mg}$ protein.

\section{Biocatalytic properties of the immobilized lipase: \\ Effect of reaction temperature}

The reaction mixtures containing native or DEAE-cellulose-immobilized lipase were incubated at different temperature ranging from $30{ }^{\circ} \mathrm{C}$ to $70{ }^{\circ} \mathrm{C}$ for 5 hours with continuous shaking at $150 \mathrm{rpm}$. The relative activities were expressed as percentage of the activities at different temperature compared to reaction temperature of $40{ }^{\circ} \mathrm{C}$. All experiments were carried out in triplicate.

\section{Effect of thermostability}

Enzymes were incubated at various temperatures ranging from $30{ }^{\circ} \mathrm{C}$ to $70{ }^{\circ} \mathrm{C}$ in sealed vials for one hour. The enzymes were left to cool at room temperature before the esterification activity. The relative activities were expressed as percentages of the relative activities at different temperature compared to the activity of the untreated enzyme. All experiments were carried out in triplicate.

\section{Effect of leaching}

The leaching procedure was done by washing the DEAE-cellulose-immobilized lipase $(0.30 \mathrm{~g})$ with hexane of 4,8 , 12,16 and $20 \mathrm{~mL}$ with additional $4 \mathrm{~mL}$ at each washing. The activities of DEAE-cellulose-immobilized lipase at each volume of hexane were determined by esterification reaction. The activity of the lipases was expressed as percentages of the relative activities at different wash cycle compared to the activity of the unwashed enzyme. All experiments were carried out in triplicate.

\section{Effect of stability in organic solvent}

The stability of the immobilized enzyme in organic solvent was compared to native lipase. The DEAE-celluloseimmobilized lipase and native lipase were incubated in hexane without shaking at room temperature starting from day one to day ten. After the incubation, the activity was determined at $30^{\circ} \mathrm{C}$. The relative activities were expressed as percentages of their activities to the different time intervals compared to the activity at day one. All experiments were carried out in triplicate.

\section{Effect of storage stability}

This study was conducted to investigate the stability of native lipase compare to immobilized lipase at different storage temperature $\left(-20{ }^{\circ} \mathrm{C}, 0{ }^{\circ} \mathrm{C}\right.$ and room temperature). Both lipases were kept for 60 days. The relative activities were expressed as percentages of esterification activities at 60 days compared to the initial activity at day one. All experiments were carried out in triplicate.

\section{Results and Discussion}

Enzyme stability can be improved by immobilization of enzymes on insoluble supports. DEAE-cellulose showed significantly high amount of protein loading up to $84 \%$ thus making it a suitable matrix for enzyme immobilization. Generally, enzyme immobilized on the support was assumed to be distributed within the support and localized at the surfaces [11]. When adsorption of enzyme was done, large protein molecule of lipase from Candida rugosa were distributed randomly in its interlayers, replacing the smaller molecules of water. Immobilization method effectiveness was determined through activities of the immobilized lipase at different conditions. High protein loading of enzyme on the support will lead to higher enzymatic activity. The enzymatic conversion of biodiesel 
butyl oleate in hexane was higher for the DEAE-cellulose immobilized lipase (89\%) compared to native lipase (45\%). Enzyme shows high chemoselectivity and mild conditions compared to harsh alkaline or acid catalysis system. This biodiesel synthesis by enzymatic esterification reactions of long fatty acids can also be expanded to other aliphatic bioalcohols (methanol, ethanol, n-propanol).

\section{Effect of reaction temperature}

Figure 1 shows the activities of the immobilized and native lipase increased at temperatures between $30{ }^{\circ} \mathrm{C}$ and $40{ }^{\circ} \mathrm{C}$. However, drastic decrease in activities occurs after $50{ }^{\circ} \mathrm{C}$. Activity of lipase was low at $30{ }^{\circ} \mathrm{C}$ may be due to the diffusion limitation of the reactant cause by the increase in reactant viscosity at lower temperature. The optimum temperature for both the enzymes was at $40{ }^{\circ} \mathrm{C}$. Lipase immobilized onto DEAE-cellulose seemed to protect the enzyme against denaturation by heat as their activities were higher compared to native lipase at temperatures higher than $50{ }^{\circ} \mathrm{C}$. Lipases are easily denatured at higher temperature where the peptide bonds and amino acid chains are reactive and can participate in deleterious reactions at high temperature. This will lead to weak stabilizing interaction that built up a conformational stability in an enzyme to be destroyed by heat. This problem can be solved by ample conformational mobility, which it can achieve through attachment on solid support [12].

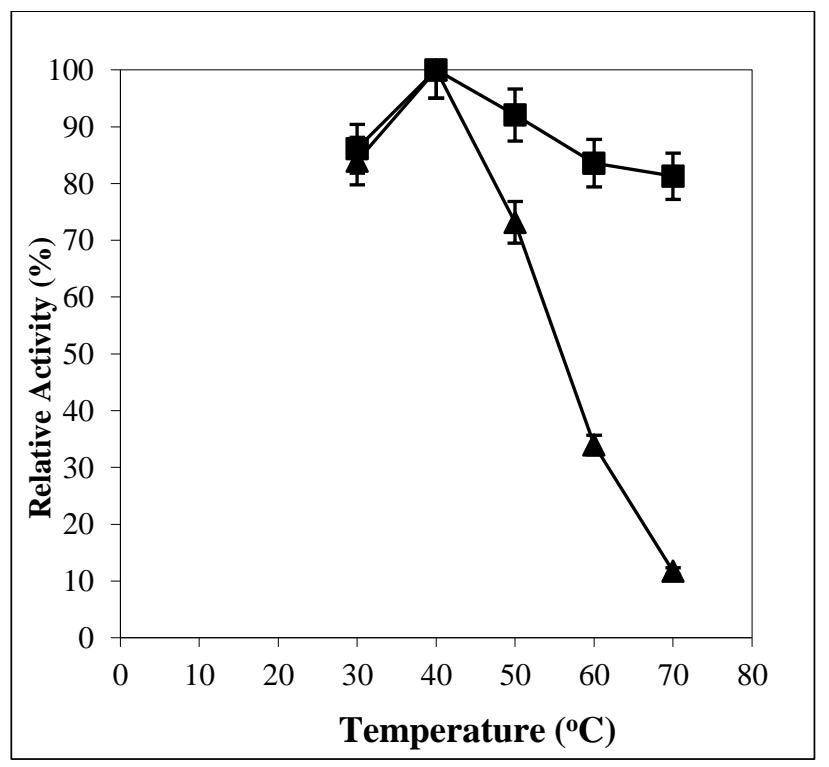

Figure 1. Effect of temperature on the relative esterification activity of DEAE-cellulose immobilized lipase and native lipase. Reactions were performed in hexane with 1:1 mole ratio of 1-butanol and oleic acid. Bars indicate standard deviation. ( $\boldsymbol{\Lambda}$ Native Lipase; Immobilized Lipase on DEAE-cellulose)

\section{Effect of thermostability}

Stability of lipase immobilized on DEAE-cellulose is shown in Figure 2. The immobilized lipase preparations were significantly more thermo-stable than the native lipase after 1 hour of incubation at temperatures ranging from $40{ }^{\circ} \mathrm{C}$ to $70{ }^{\circ} \mathrm{C}$. The immobilized lipase had higher activity than native lipase because the immobilization can perform its vibrational and more complex movement required for efficient catalyst activity. At temperatures above $30{ }^{\circ} \mathrm{C}$, enzyme resistance to adverse heat influences and persistency of its molecular integrity to face denaturants were deteriorated. This denaturation is due to a fully functional monomeric enzyme loses its biological activity in vitro by unfolding of its tertiary structure to a disordered polypeptide. Nevertheless, finding has shown that besides temperature and $\mathrm{pH}$, presence of chaotropic agents also influences denaturation of these enzymes. Denaturation of these enzymes occurs in an equivalent way, encouraging unfolding of the three-dimensional protein structure [13]. In most models of thermal deactivation, an active lipase undergoes a reversible or irreversible structural change (i.e. a temperature-induced conformational transition) to produce a catalytically inactive form because such process is essentially unimolecular, it is frequently characterized by first-order kinetics. 


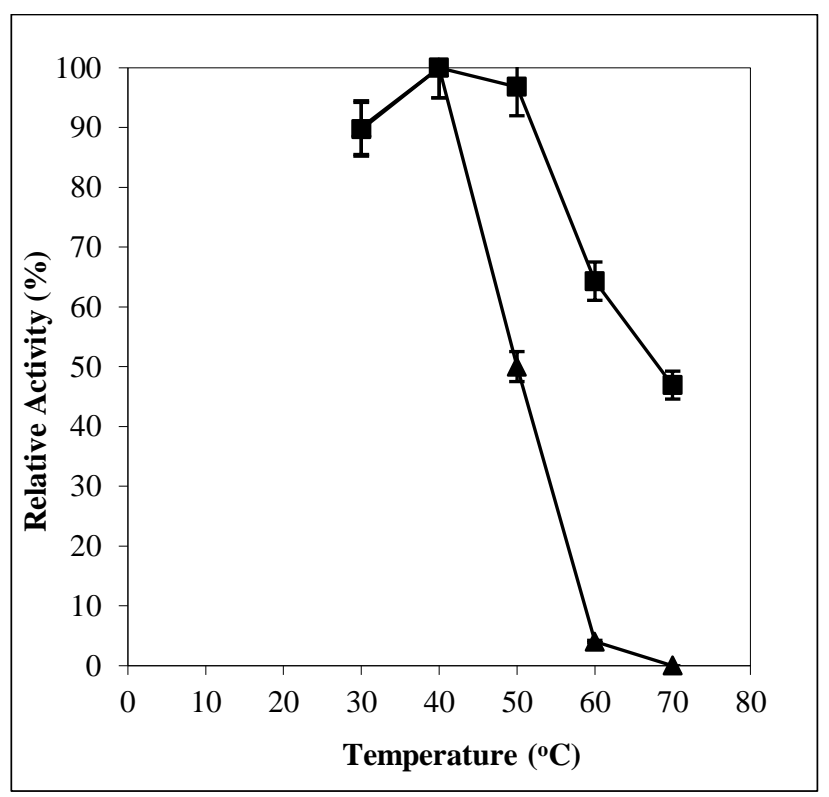

Figure 2. Percent relative activity of native lipase and DEAE-cellulose immobilized lipase after 1 hour incubation at various temperatures. Reactions were performed in hexane with 1:1 mole ratio of 1-butanol and oleic acid at $30^{\circ} \mathrm{C}$. Bars indicate standard deviation. ( $\Delta$ Native Lipase; Immobilized Lipase on DEAEcellulose)

\section{Stability in hexane}

The stability evaluation of enzyme preparations in hexane is shown in Figure 3.

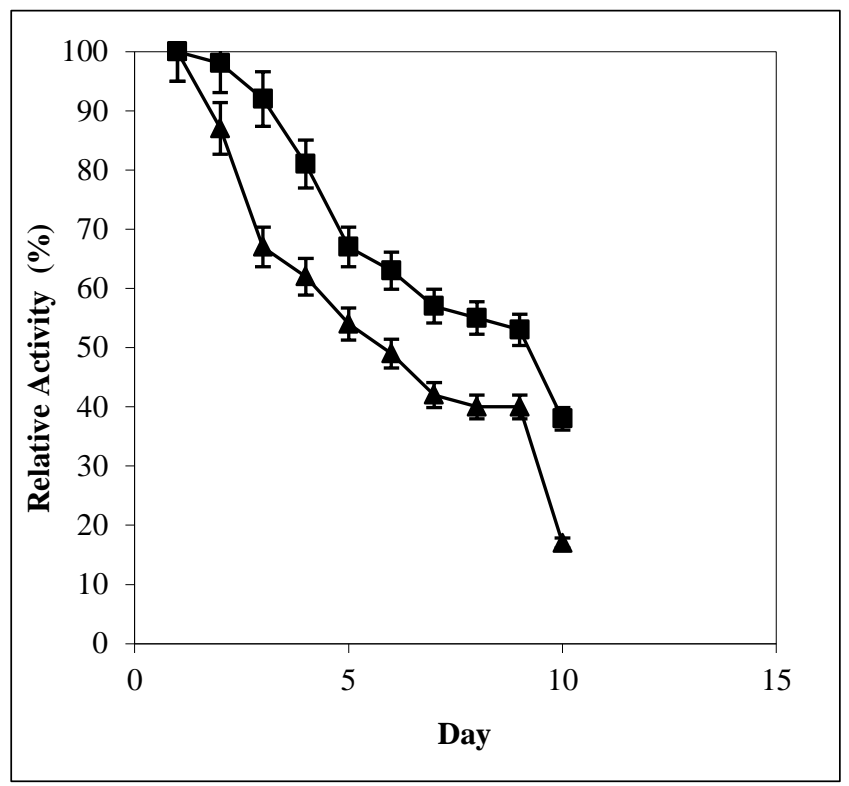

Figure 3. Percent relative activity of native lipase and DEAE-cellulose immobilized lipase as affected by incubation in hexane at room temperature $\left(25^{\circ} \mathrm{C}\right)$ from day 1 to day 10 . Reactions were performed in hexane with 1:1 mole ratio of 1-butanol and oleic acid at $30^{\circ} \mathrm{C}$. Bars indicate standard deviation. ( $\triangle$ Native Lipase; - Immobilized Lipase on DEAE-cellulose) 
Stability of the lipase immobilized onto DEAE-cellulose remained stable at $50 \%$ of its relative activities compared to native lipase (40\%) when incubated in hexane at room temperature up to 9 days. Immobilization seemed to protect the enzyme from denaturation caused by the presence of organic solvent. Supports may induce water molecules surrounding lipase, which was necessary for its catalytic activities from being stripped away by organic solvent [14]. The essential water layer around the enzyme must be preserved to maintain the active conformation of enzyme. A large amount of water may result to the undesirable side reaction such as hydrolysis of acid anhydrides and halogenates. The thermodynamic equilibrium of most processes is unfavorable in water. Therefore, enzyme may be stable in organic solvents than they are in water and this is the reason why they are used as reaction medium in enzymatic activities. Although the polar solvent tends to strip water from enzyme molecule, the supports may trap and prevent disruption of the enzyme bound water essential to maintain the three-dimensional structure of the enzyme for catalysis [15].

\section{Leaching study on immobilized lipase}

Figure 4 shows that all the derivatized lipase preparations retained their catalytic activities at $100 \%$ even after 4 washing cycles. The fifth cycle showed only a slight leached not more than $1 \%$ for all the immobilized lipase. This might reflect the loss of some enzyme during washing and be an inherent consequence of its immobilization on each support surface [16]. This finding is an indication that lipase remained immobilized on the support even after washing with $20 \mathrm{~mL}$ of hexane. With this, DEAE-cellulose is proven to be suitable support for enzyme immobilization as it prevents enzyme from being washed away. This also proved that the method of adsorption used in this study is a suitable method of immobilization and had been successfully done [17].

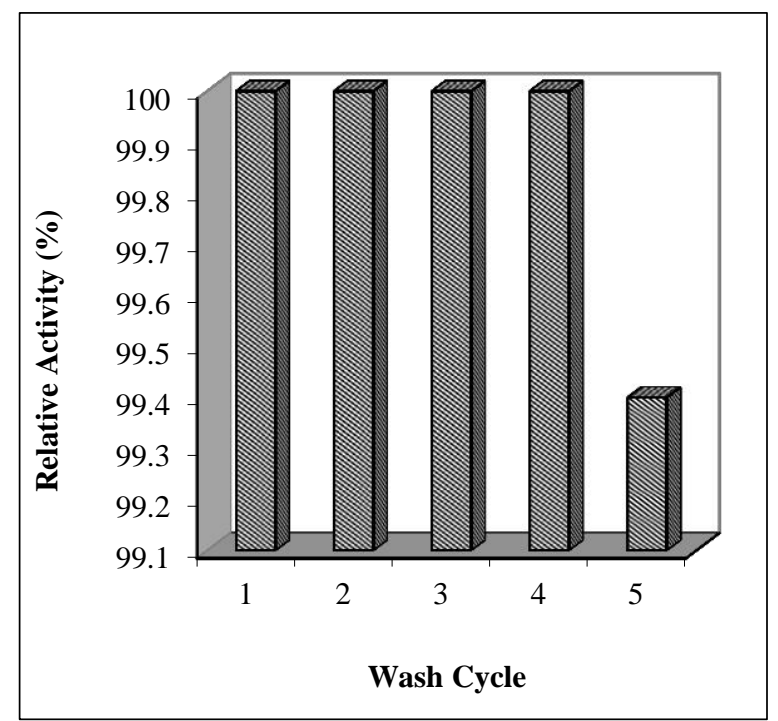

Figure 4. Effect of leaching on the relative esterification activity of DEAE-cellulose immobilized lipase. Reactions were performed in hexane with 1:1 mole ratio of 1-butanol and oleic acid at $30^{\circ} \mathrm{C}$

\section{Storage stability}

The residual activities of various lipase preparations were determined after storing for 60 days under various conditions. All lipases exhibited full catalytic activity after storing them at $-20{ }^{\circ} \mathrm{C}$. Immobilized lipase also retained their catalytic activity at $100 \%$ when stored at $0{ }^{\circ} \mathrm{C}$ but decreased to $65 \%$ for the storage at room temperature. The native lipase was able to retain $70 \%$ of activity for $0{ }^{\circ} \mathrm{C}$ storage but decreased abruptly to $25 \%$ of activity when stored at room temperature. At very low temperatures, lipase is probably locked in its native, catalytically active conformation. Immobilized lipase showed increase in storage stability compared to native lipase, when stored at higher temperatures. At these temperatures, the stabilization may be owed to the multipoint attachment of the enzymes to the supports, creating a more rigid enzyme molecule. Hence disruption of the active centre becomes less likely to occur [18]. 


\section{Conclusion}

Lipase from Candida rugosa has been successfully immobilized on DEAE-cellulose using physical adsorption method. The method employed was a success referring to the increase in activity and stability of lipase after immobilization. Immobilized lipase was found to be more stable compared to the native lipase under higher temperature, in solvent and under different storage conditions. DEAE-cellulose had satisfied a number of criteria as it allows easy lipase immobilization without having to lose its catalytic activity and it can be obtained through simple and inexpensive method. This environmental friendly and mild reaction conditions of butyl oleate production for biodiesel could be a better choice for industrial application.

\section{Acknowledgement}

This project was supported by the Ministry of Science, Technology and Innovation, Malaysia research grant (Vot. No. 5450618).

\section{References}

1. Abdul Rahman, M. B., Basri, M., Hussein, M. Z., Rahman, R. N. Z. A., Zainol, D. H. and Salleh, A. B. (2004). Immobilization of lipase from Candida Rugosa on layered double hydroxides for esterification reaction. Applied Biochemistry and Biotechnology - Part A Enzyme Engineering and Biotechnology, 118: 313-320.

2. Zaidan, U. H., Rahman, M. B. A., Basri, M., Othman, S. S., Rahman, R. N. Z. R. A. and Salleh, A. B. (2010). Silylation of mica for lipase immobilization as biocatalysts in esterification. Applied Clay Science, 47: 276-282.

3. Lian, X., Fang, Y., Joseph, E., Wang, Q., Li, J., Banerjee, S., Lollar, C., Wang, X. and Zhou, H. C. (2017). Enzyme-MOF (Metal-Organic Framework) composites. Chemical Society Reviews, 46: 3386 - 3401.

4. Liu, D., Chen, J. and Shi, Y. (2018). Advances on methods and easy separated support materials for enzymes immobilization. Trends in Analytical Chemistry, 102: 332-342.

5. Sirisha, V. L., Ankita, J. and Amita, J., (2016). Enzyme immobilization: An overview on methods, support material, and applications of immobilized enzymes. Advances in Food and Nutrition Research, 79: 179-211.

6. O'Neill, S. P., Dunnill, P. and Lilly, M. D. (1971). A comparative study of immobilized amyglucosidase in a packed bed reactor and a continuous stirred tank reactor. Biotechnology and Bioengineering, 13: 337-352.

7. Fradet, H., Arnaud, A., Rios, G. and Galzy, P. (1985). Hydration of nitriles using a bacterial nitrile-hydratase using DEAE-cellulose. Biotechnology and Bioengineering, 27: 1581-1585.

8. Othman, S. S., Basri, M., Hussein, M. Z., Abdul Rahman, M. B., Rahman, R. N. Z. A., Salleh, A. B., and Jasmani, H. (2008). Production of highly enantioselective (-)-methyl butyrate using Candida Rugosa lipase immobilized on epoxy-activated supports. Food Chemistry, 106(2): 437-443.

9. Stoytcheva, M. and Montero, G. (2011). Biodiesel: Feedstocks and processing technologies, In. Tech, Croatia: pp. 397-410.

10. Bradford, M. M. (1976). A rapid and sensitive method for the quantitation of microgram quantities of protein utilizing the principle of protein-dye binding. Analytical Biochemistry, 72: 248-254.

11. Abdul Rahman, M. B., Md. Yunus, N. M., Othman, S. S., Basri, M., Salleh, A. B. and Rahman, R. N. Z. A. (2006). New lipases and proteases, Nova Science Publishers, Inc. New York: pp. 111-125.

12. Paiva, A. L., Balcão, V. M. and Malcata, F. X. (2000). Kinetics and mechanisms of reactions catalyzed by immobilized lipases. Enzyme and Microbial Technology, 27(3-5): 187-204.

13. Becktell, W. J. and Schellman, J. A. (1987). Protein stability curves. Biopolymers, 26: 1859-1877.

14. Klibanov, A. M. (1986). Enzymes that work in organic solvents. Chemtech: 54-359.

15. Gorman, L. A. and Dordick, J. S. (1992). Organic solvents strip water off enzymes. Biotechnology and Bioengineering, 39: 392-397.

16. Abdul Rahman, M. B., Md Yunus, N. M., Hussein, M. Z., Rahman, R. N. Z. A., Salleh, A. B. and Basri, M. (2005). Application of advanced materials as support for immobilisation of lipase from Candida rugosa. Biocatalysis and Biotransformation, 23: 233-239.

17. Zaidan, U. H., Abdul Rahman, M. B., Othman, S. S., Basri, M., Abdulmalek, E., Abdul Rahman, R. N. Z. R. and Salleh, A. B. (2012). Biocatalytic production of lactose ester catalysed by mica-based immobilised lipase. Food Chemistry, 131(1): 199-205.

18. Bosley, J. (1997). Turning lipases into industrial biocatalysts. Biochemical Society Transactions, 25: 174-178. 